\title{
ANALISIS CERPEN “LELAKI RAGI DAN PEREMPUAN SANTAN” KARYA DAMHURI MUHAMMAD DENGAN PENDEKATAN EKSPRESIF
}

\author{
Ubai Dillah Al Anshori \\ Pengkajian Seni Teater \\ Fakultas Seni Pertunjukan \\ Institut Seni Indonesia Padangpanjang
}

\begin{abstract}
Abstrak
Penelitian ini bertujuan untuk mengetahui gambaran ekspresi pengarang dalam cerpen Lelaki Ragi dan Perempuan Santan. Sumber data dalam penelitian ini adalah cerpen Lelaki Ragi dan Perempuan Santan karya Damhuri Muhammaad yang diterbitkan oleh Marjin Kiri dan merupakan salah satu dari kumpulan cerpen Anak-Anak Masa Lalu karya Damhuri Muhammad dengan tebal 121 halaman, cetakan pertama, Juni 2015. Data penelitian ini adalah ekspresi pengarang dalam cerpen Lelaki Ragi dan Perempuan Santan. Metode yang digunakan dalam penelitian ini adalah metode deskriptif. Instrumen dalam penelitian ini adalah pedoman dokumentasi. Teknik analisis datanya yakni dengan cara membaca secara beulang-ulang dengan cermat, menghayati dan memahami cerpen Lelaki Ragi dan Perempuan Santan, mengumpulkan data dari isi cerita cerpen yang behubungan dengan gambaran ekspresi pengarang dalam cerpen Lelaki Ragi dan Perempuan Santan, melakukan telaah data dan menggaris bawahi kata dalam isi cerita, dialog, dan perilaku tokoh yang terdapat gambaran espresi pengarang dalam cerpen Lelaki Ragi dan Perempuan Santan, mendeskripsikan ekspresi pengarang yang terdapat dalam cerpen Lelaki Ragi dan Perempuan Santan, menarik kesimpulan dari hasil penelitian. Hasil yang diperoleh yakni terdapat gambaran ekspresi pengarang yaitu timbulnya rasa kesetiaan, kecewa, sabar, gigih dan khawatir tokoh dalam cerpen Lelaki Ragi dan Perempuan Santan.
\end{abstract}

Kata Kunci : Cerpen, Pendekatan Eksprensif

\section{Pendahuluan}

Kehadiran sastra tidak terlepas dari kematangan pengarang dalam menumpahkan ide dan gagasan yang menarik minat masyarakat agar terus membaca dan melahap keindahan hasil karya sastra. Setiap pengarang dapat melukiskan imajinasinya ke dalam sebuah karya sastra yang sangat matang. Baik dari segi bahasa maupun tema yang akan diangkat. Pengarang yang lahir dengan sempurna akan mampu melukiskan karya sastra melalui pengalaman pribadi maupun pengalaman orang lain. Pengalaman, pikiran dan imajinasi pengarang akan melewati sebuah proses yang nikmat baginya, di mana sebuah ketiadaan 
akan menjadi sesuatu yang ada yaitu tulisan dan mewujudkan pada tokoh dan cerita yang ditulis pengarang.

Setiap pengarang sebagai tokoh utama di balik lahirnya karya sastra. Pengarang merupakan bagian terpenting. Selain dari itu, pengarang adalah manusia yang tidak bisa lepas dari lingkungan masyarakat yang membendungnya. Ia berada dalam lingkaran dengan berbagai macam bentuk masyarakat serta pola pikir, perilaku dan corak budaya yang berbeda-beda.Terlepas dari tokoh dan cerita. Setiap pengarang melahirkan karya sastranya tidak hanya didorong oleh hasrat untuk menciptakan keindahan tetapi juga berkehendak untuk menyampaikan pikiran serta pendapat.

Karya sastra besar memberi kesadaran kepada pembacanya tentang kebenarankebenaran hidup ini. Darinya kita dapat memperoleh pengetahuan dan pemahaman yang mendalam tentang manusia, dunia, dan kehidupan (Sumardjo, 1986:8). Lalu, dalam lahirnya sebuah karya sastra yang dijahit dengan benang yang saling berkaitan serta daya ekspresi pengarang senantiasa tumbuh dan berkembang sehingga muncul berbagai variasi teknik penulisan, gaya, dan berbagai jenis kelainan ekpresi. Gambaran ekspresi pengarang pada akhirnya menjadi sebuah perjalanan yang menarik untuk diketahui. Sehubungan dengan itu, ketertarikan peneliti untuk membahas lebih dalam cerpen Lelaki Ragi dan Perempuan Santan karena kesetiaan Lelaki Ragi yang bersetia untuk tetap bersatu dengan Perempuan Santan.

Pendekatan ekspresif tidak semata-mata memberikan perhatian terhadap bagaimana karya sastra itu diciptakan, seperti studi proses kreatif dalam studi biografis, tetapi bentukbentuk apa yang terjadi dalam karya sastra yang dihasilkan (Ratna, 2004:68). Gambaran ekspresi pengarang pada akhirnya menjadi sebuah perjalanan yang menarik untuk diketahui serta dimatangkan dalam jiwa para pembaca agar tetap mengapresiasi karya sastra baik sekarang maupun yang akan datang.

\section{Pendekatan Ekspresif}

Abrams (dalam Teeuw, 1988:50) "Mengemukakan empat pendekatan dalam melihat karya sastra." pertama, pendekatan mimetik adalah pendekatan yang bertolak pada pandangan bahwa karya sastra merupakan suatu tiruan atau penggambaran dunia dari kehidupan manusia. Pendekatan mimetik menganggap karya sastra sebagai tiruan alam, kehidupan atau dunia ide.

Kedua, pendekatan pragmatik adalah pendekatan yang menganut prinsip bahwa karya sastra yang baik ialah karya sastra yang dapat memberi kesenangan dan manfaat bagi 
pembacanya Soeranto dalam (Suwardi, 2013:117) berpendapat bahwa pragmatik sastra, berwawasan bahwa karya sastra sebagai produk yang menawarkan pandangan, saran, harapan, dan langkah-langkah untuk mencapai kejelasan bahwa karya sastra perlu diteliti tidak saja dari aspek retorika yang mengakibatkan pembaca tertarik, melainkan apa yang dilakukan pembaca setelah menikmati karya sastra.

Ketiga, pendekatan objektif adalah pendekatan yang memandang dan menelaah sastra dari segi intrinsik yang membangun sebuah karya sastra. Dengan kata lain, pendekatan ini memandang dan menelaah sastra dari segi intrinsik yang membangun suatu karya sastra, yaitu tema, alur, latar, penokohan dan gaya bahasa.

Keempat, pendekatan ekspresif adalah pendekatan yang mendasarkan pada pencipta atau pengarang karya sastra. Semi (1989:44) mengemukakan "Pendekatan ekspresif menitikberatkan perhatian kepada upaya pengarang atau penyair mengekspresikan ideidenya ke dalam karya sastra. Kemampuan pengarang menyampaikan pikiran yang agung dan emosi yang kuat menjadikan ukuran keberhasilan. Pendekatan ekspresif ini tidak semata-mata memberikan perhatian terhadap bagaimana karya itu diciptakan. Tetapi, bentuk-bentuk apa yang terjadi dalam karya sastra yang dihasilkan. Pendekatan ini dapat dimanfaatkan untuk menggali ciri-ciri individualisme, nasionalisme, komunisme, feminisme, dan sebagainya dalam karya baik karya sastra individual maupun karya sastra dalam kerangka periodisasi. Praktik pendekatan ini mengarah pada penelusuran kesejatian visi pribadi pengarang yang secara sadar atau tidak telah membukakan dirinya dalam karya tersebut.

Langkah-langkah dalam penerapan ekspresif antara lain, yaitu Langkah pertama, seorang kritikus harus mengenal biografi pengarang karya sastra yang akan diuji. Langkah kedua, melakukan penafsiran pemahaman terhadap unsur-unsur yang terdapat dalam karya sastra, seperti tema, gaya bahasa/diksi, citraan, dan sebagainya. Langkah ketiga, mengaitkan hasil penafsiran dengan berdasarkan tinjauan psikologis kejiwaan pengarang.

Pengarang ketika melakukan proses penciptaan karya sastra. Pengarang menciptakannya berdasarkan subjektifitasnya saja, bahkan ada yang beranggapan arbitrer. Padahal, ekspresif yang dimaksud berkenaan dengan daya kontemplasi pengarang dalam proses kreatifnya, sehingga menghasilkan sebuah karya yang baik dan sarat makna. Para kritikus ekspresif meyakini bahwa sastrawan (pengarang) karya sastra merupakan unsur pokok yang melahirkan pikiran-pikiran, persepsi-persepsi dan perasaan yang dikombinasikan dalam karya sastra. Kritikus cenderung menimba karya sastra berdasarkan kemulusan, kesejatian, kecocokan penglihatan mata batin pengarang/keadaan pikiranya. 
Kisaran ekspresif terletak pada soal mengkaji emosi, gagasan, imajinasi dan seterusnya yang dimiliki pengarang yang dikaitkan dengan karya yang diciptakan pengarang. Dalam proses interpretasi, pengarang menjadi penentu pemberian makna apa yang dapat dikonkretkan. Arah penginterpretasian dan pemaknaan seperti ini dalam hermeneutika lebih mengikuti cara-cara yang dilakukan hermeneutika tradisional. Jadi, faktor eksternal di luar teks yakni pengarang menjadi penentu makna sebuah teks yang dikaji. Soeryabrata dalam Siswanto (2008:12) menambahkan "Aktivitas manusia mencakup perhatian, pengamatan, tanggapan, fantasi, ingatan, pikiran, perasaan, dan motif-motif. Hal ini juga berlaku bagi individu pengarang”. Kepribadian pengarang terbagi atas beberapa macam, agar menjadikan pengarang dapat melahirkan hasil karya yang matang.

Kepribadian pengarang adalah pengetahuan. Pengetahuan adalah unsur-unsur yang mengisi akal dan alam jiwa seorang manusia yang sadar, secara nyata terkandung dalam otaknya. Pengetahuan bisa terdiri atas persepsi, apersepsi, pengamatan, konsep, dan fantasi. Banyak pengetahuan pengarang terpaparkan saat terdesak ke alam bawah sadar. Dalam alam bawah sadar banyak pengetahuan individu larut dan pecah-pecah menjadi bagianbagian yang sering kali bercampur satu dengan yang lain. Bagian-bagian pengetahuan tadi mungkin muncul lagi di alam kesadaran individu. Pengetahuan seorang individu dapat juga terdesak atau dengan sengaja didesak oleh individu ke dalam bagian jiwa manusia yang lebih dalam lagi, yaitu alam tidak sadar. Di alam ini, pengetahuan individu larut dan terpecah-pecah ke dalam bagian-bagian yang saling berbaur dan tercampur. Bagian ini kadang bisa muncul kembali, yaitu pada saat-saat akal yang mengatur alam kesadaran individu berada dalam keadaan lemah atau tidak berfungsi.

Kepribadian adalah perasaan. Perasaan adalah suatu keadaan dalam kesadaran manusia yang karena pengaruh pengetahuannya dinilai sebagai keadaan positif atau negatif. Perasaan dapat menimbulkan kehendak, yaitu keadaan untuk mendapatkan suatu kenikmatan (kehendak positif) atau menghindari hal yang dirasakannya sebagai hal yang akan membawa perasaan tidak nikmat kepadanya. Melalui kerja kreatifnya, pengarang menjaga agar tidak menjadi gila tetapi sekaligus juga agar tidak dapat disembuhkan". Menjelaskan bahwa pengarang adalah pelamun yang diterima masyarakat. Pengarang tidak perlu mengubah kepribadiannya dia boleh meneruskan dan mempublikasikan lamunannya yang kretif dan menumbuhkan karya-karya melalui akar lamunannya. Kepribadian adalah dorongan naluri. Dorongan naluri adalah kemauan yang sudah tertanam pada setiap manusia yang tidak ditimbulkan karena pengaruh pengetahuannya, melainkan karena sudah 
berlangsung dalam jiwanya. Berdasarkan hasil ungkapannya ekspresi manusia dapat dibedakan antara ekspresi kreatif dan ekspresi tidak kreatif.

1. Ekspresi kreatif adalah perasaan manusia yang ungkapannya diselaraskan dengan jenis ciptaan karya seni misalnya: seni rupa, musik, tari, drama atau sastra.

2. Ekspresi tidak kreatif adalah perasaan manusia yang ungkapannya tidak menghasilkan karya seni, sesuatu merupakan ungkapan yang membebaskan diri dari rasa tertentu. Misalnya: marah, menangis, menjerit, dan lain sebagainya.

Jika dilihat dari sudut penutur mengungkapkan emosi bukan hanya lewat bahasa saja, tetapi memperlihatkan emosi itu sewaktu menyampaikan tuturannya

\section{Metode Penelitian}

Dalam menyelesaikan sebuah karya ilmiah, harus dipakai metode yang dapat membantu, adapun metode yang akan peneliti gunakan adalah metode deskriptif. Dengan metode deskriptif, data diperoleh melalui analisis cerpen Lelaki Ragi dan Perempuan Santan karya Damhuri Muhammad dengan pendekatan ekspresif. Metode ini didasarkan atas pertimbangan akan adanya kesesuaian antara bentuk dan tujuan peneliti.

\section{PEMBAHASAN DAN HASIL PENELITIAN}

Setelah membaca cerpen Lelaki Ragi dan Perempuan Santan karya Damhuri Muhammad, peneliti merasakan kenikmatan-kenikmatan dari pengarang untuk mengetahui lebih lanjut dunia batin pengarang. Oleh karena itu, peneliti menganalisis cerpen Lelaki Ragi dan Perempuan Santan dengan pendekatan ekspresif. Gambaran ekspresi pengarang dapat dilihat pada tabel 4.1 di bawah ini.

Tabel 1

Gambaran Ekspresi Pengarang dalam Cerpen Lelaki Ragi dan

Perempuan Santan

\begin{tabular}{|l|l|c|c|}
\hline Tokoh & Nomor & $\begin{array}{c}\text { Gambaran Ekspresi } \\
\text { Pengarang }\end{array}$ & Halaman dan Kutipan Dalam Cerpen \\
\hline
\end{tabular}




\begin{tabular}{|c|c|c|c|}
\hline Lelaki Ragi & 1 & Kesetiaan & $\begin{array}{l}\text { "Lantaran lemang-tapai itu, kuabaikan rantang- } \\
\text { rantang gulai kentang yang datang silih berganti. } \\
\text { Kau tahu, di kampung ini hantaran gulai kentang } \\
\text { adalah bahasa pinangan paling santun. Mungkin } \\
\text { tampak murah dan sederhana sebab tanpa campuran } \\
\text { daging tapi ia mengandung kiasan yang } \\
\text { kedalamannya hingga kini belum tergantikan." } \\
\text { halaman 55). "Tapi, aku memilih bertahan di } \\
\text { kampung karena tak ingin jauh darimu. Selain itu, } \\
\text { aku satu-satunya anak ibu yang masih tersisa di } \\
\text { kampung. Sebelum pergi, aku ingin merawat } \\
\text { orangtua dan menjaga mereka. "(halaman 56). "Kau } \\
\text { masih menunggu anak si tukang lemang itu? } \\
\text { Sudah tiga anaknya," kata ibu suatu petang } \\
\text { " Banyak gadis muda di sini. Tak satu pun yang kau } \\
\text { suka?" } \\
\text { Rantang-rantang gulai kentang masih berdatangan, } \\
\text { Ada yang datang membawa puji, ada yang tiba } \\
\text { menjunjung janji, bahkan ada yang meminang dua- } \\
\text { tiga kali." (halaman } 61 \text { ). }\end{array}$ \\
\hline & 3 & Sabar & $\begin{array}{l}\text { "Sudah berkali-kali aku membawanya berobat dan } \\
\text { menjalani terapi, namun, Ayah tetap saja lumpuh, } \\
\text { pita suaranya seperti terlipat, dan hanya bisa } \\
\text { menangis ketiak dijenguk para kerabat. Karena sibuk } \\
\text { mengurus Ayah, aku tidak terlalu memikirkan } \\
\text { kendurimu yang tentu semarak dan bergelimang } \\
\text { kemewahan" (halaman 60). " Saban pagi } \\
\text { kumandikan, kusuapi makannya, dan kudorong kursi } \\
\text { rodanya untuk menghirup udara pagi" (halaman 61). }\end{array}$ \\
\hline
\end{tabular}




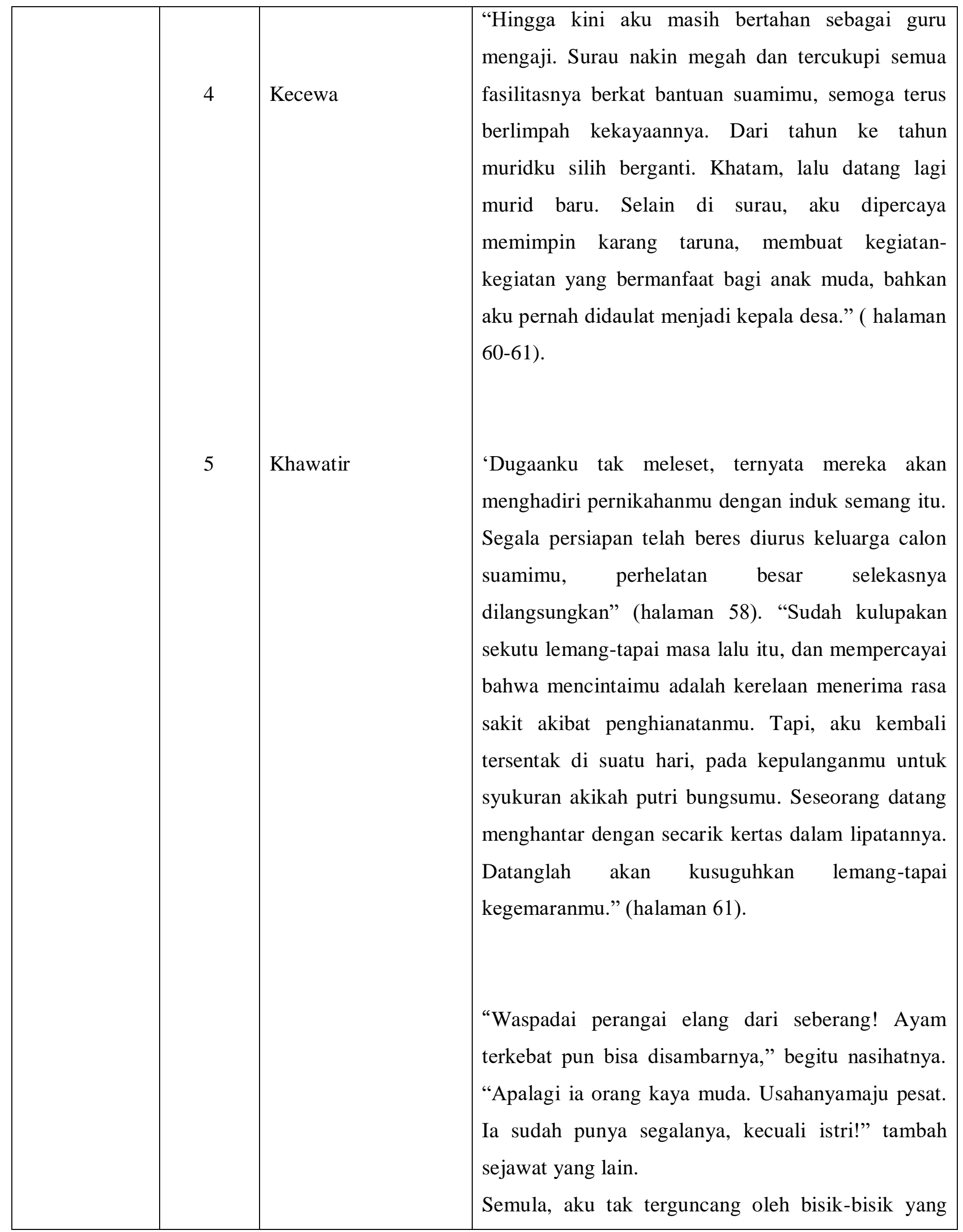




\begin{tabular}{|l|l|l|}
\hline \multicolumn{1}{|l|}{$\mid \begin{array}{l}\text { terus mengusik itu. Aku percaya, kau juga punya } \\
\text { siasat penolakan yang lemah-lembut, sebagaimana } \\
\text { yang kulakukan pada setiap hantaran gulai kentang. } \\
\text { Lagi pula, bukankah kau lemang yang masih } \\
\text { bersetia pada tapai? } \\
\text { Namun, tak lama setelah kepulangan orang kaya } \\
\text { muda itu, tersiar kabar bahwa ia ternyata telah } \\
\text { menawarkan pekerjaan sebagai kasir di salah satu } \\
\text { restoran miliknya di Jakarta." ( halaman 57). }\end{array}$} \\
\hline
\end{tabular}

\section{Ekspresi Pengarang dalam Cerpen Lelaki Ragi dan Perempuan Santan}

Melalui cerpen Lelaki Ragi dan Perempuan Santan dapat dilihat bagaimana gambaran ekspresi pengarang dalam karya sastra tersebut. Perasaan-perasaan yang sedang dialami pengarang mulai dari setia, sabar, gigih, kecewa dan khawatir. Hasil analisis data adalah sebagai berikut:

\section{a. Kesetiaan}

Setia pada dasarnya adalah kata yang sangat mudah untuk diucapkan tetapi sangat sulit untuk dilaksanakan. Tak jarang, seseorang yang telah menjadi perantauan akan lupa dengan janji dan beralih ke perempuan atau ke lelaki lain. Dalam cerpen tersebut, Kesetiaan Ragi dapat diberikan penghargaan, dalam kesempatan bagaimana pun usahanya untuk menolak hantaran-hantaran gulai kentang, demi menuntaskan cinta pada Santan. Terlihat pada kutipan di bawah ini:

"Lantaran lemang-tapai itu, kuabaikan rantang-rantang gulai kentang yang datang silih berganti. Kau tahu, di kampung ini hantaran gulai kentang adalah bahasa pinangan paling santun. Mungkin tampak murah dan sederhana sebabtanpa campuran daging tapi ia mengandung kiasan yang kedalamannyahingga kini belum tergantikan." ( halaman 55).

Kesetiaan tidak hanya dilakukan pada seorang kekasih. Bagaimanapun orangtua yang membesarkan dan memberikan kasih sayang yang tiada henti akan diberikan kasih sayang untuk merawatnya sampai akhir hayat. Begitu juga dengan Ragi yang juga 
mempunyai kesetiaan untuk terus berdekap di kampung, dan merawat kedua orangtuanya. Terlihat pada kutipan di bawah ini.

“Tapi, aku memilih bertahan di kampung karena tak ingin jauh darimu. Selain itu, aku satu-satunya anak ibu yang masih tersisa di kampung. Sebelum pergi, aku ingin merawat orangtua dan menjaga mereka." (halaman 56).

Kesetiaan Ragi masih sangat melekat di jiwanya, bahkan sesekali ibunya menanyakan hal tentang percintaannya kepada Santan yang saat ini sudah mulai basi. Terlihat pada kutipan di bawah ini:

"Kau masih menunggu anak si tukang lemang itu?

Sudah tiga anaknya, " kata ibu suatu petang

"Banyak gadis muda di sini. Tak satu pun yang kau suka?”

Rantang-rantang gulai kentang masih berdatangan, Ada yang datang membawa puji, ada yang tiba menjunjung janji, bahkan ada yang meminang dua-tiga kali." (halaman 61).

\section{b. Sabar}

Sabar dalam KBBI adalah tahan menghadapi cobaan (tidak lekas marah, tidak lekas putus asa, tidak lekas patah hati). Beberapa hal itu sangat melekat dalam diri Ragi, ketika dirinya harus merawat orangtuanya yang sakit dan tak kunjung membaik. Serta, masalah demi masalah terus berdatangan demi menghancurkan keinginannya berbuah madu. Terlihat pada kutipan di bawah ini:

"Sudah berkali-kali aku membawanya berobat dan menjalani terapi, namun, Ayah tetap saja lumpuh, pita suaranya seperti terlipat, dan hanya bisa menangis ketiak dijenguk para kerabat. Karena sibuk mengurus Ayah, aku tidak terlalu memikirkan kendurimu yang tentu semarak dan bergelimang kemewahan” (halaman 60). “ Saban pagi kumandikan, kusuapi makannya, dan kudorong kursi rodanya untuk menghirup udara pagi" (halaman 61).

\section{c. Gigih}

Gigih adalah keras hati, tetap teguh pendirian dan pikiran. Ragi memiliki watak seperti itu. ia terus-menerus memajukan surau hingga anak-anak kampung silih berganti untuk khatam, dan fasilitas surau kini memadai. Terlihat pada kutipan di bawah ini: 
"Hingga kini aku masih bertahan sebagai guru mengaji. Surau nakin megah dan tercukupi semua fasilitasnya berkat bantuan suamimu, semoga terus berlimpah kekayaannya. Dari tahun ke tahun muridku silih berganti. Khatam, lalu datang lagi murid baru. Selain di surau, aku dipercaya memimpin karang taruna, membuat kegiatan-kegiatan yang bermanfaat bagi anak muda, bahkan aku pernah didaulat menjadi kepala desa." ( halaman 60-61).

\section{d. Kecewa}

Kecewa dalam KBBI adalah kecil hati, tidak puas (karena tidak terkabul keinginannya, harapannya dan sebagainya). Langit seakan pecah ketika kekecewaan bersarang di jantung Ragi, sebagaimana dugaannya tak meleset. Santan sudah mengingkari perjanjiannya dengan Ragi dan berdalih ke lain lelaki. Ragi merasa kecil hati dan kekecewaannya terlihat pada kutipan di bawah ini:

'Dugaanku tak meleset, ternyata mereka akan menghadiri pernikahanmu dengan induk semang itu. Segala persiapan telah beres diurus keluarga calon suamimu, perhelatan besar selekasnya dilangsungkan” (halaman 58).

Kekecewaan masih tetap dirasakan Ragi. Bagaimana tidak, penghianatan demi penghianatan masih diraupnya. Masih dengan cinta pada Santan. Pada suatu petang undangan akikah putri bungsu Santan disuguhkan kehadapannya. Terlihat pada kutipan di bawah ini:

"Sudah kulupakan sekutu lemang-tapai masa lalu itu, dan mempercayai bahwa mencintaimu adalah kerelaan menerima rasa sakit akibat penghianatanmu. Tapi, aku kembali tersentak di suatu hari, pada kepulanganmu untuk syukuran akikah putri bungsumu. Seseorang datang menghantar dengan secarik kertas dalam lipatannya. Datanglah akan kusuguhkan lemang-tapai kegemaranmu." (halaman 61).

\section{e. Khawatir}

Kedatangan orang kaya muda ke rumah Santan menimbulkan kekhawatiran yang mendalam pada Santan. Ia berharap kalau Santan akan menolak hantaran gulai kentang dari orang kaya itu. Terlihat pada kutipan di bawah ini:

"Waspadai perangai elang dari seberang! Ayam terkebat pun bisa disambarnya," begitu nasihatnya. 
"Apalagi ia orang kaya muda. Usahanya maju pesat. Ia sudah punya segalanya, kecuali istri!’ tambah sejawat yang lain.

Semula, aku tak terguncang oleh bisik-bisik yang terus mengusik itu. Aku percaya, kau juga punya siasat penolakan yang lemah-lembut, sebagaimana yang kulakukan pada setiap hantaran gulai kentang. Lagi pula, bukankah kau lemang yang masih bersetia pada tapai?

Namun, tak lama setelah kepulangan orang kaya muda itu, tersiar kabar bahwa ia ternyata telah menawarkan pekerjaan sebagai kasir di salah satu restoran miliknya di Jakarta." ( halaman 57).

\section{Kesimpulan}

Kesimpulan yang dapat di ambil dari analisis data di atas ialah bahwa gambaram ekspresi yang tertuang di dalam cerpen Lelaki Ragi dan Perempuan Santan adalah bentuk kejiwaan serta ekspresi pengarang. Segala watak, sifat dan kekecewaan benar dialami oleh pengarang. Lahir dari batin dan nurani yang sangat padu dengan berjalannya alur cerita, menggambarkan ekspresi yang dirasakan pengarang.

\section{Daftar Pustaka}

Endraswara Suwardi 2013 Metodologi Penelitian Sastra : CAPS (Center for Academic Publishing Service).

Muhammad, Damhuri. 2015. Anak-anak Masa Lalu. Depok: Marjin Kiri.

Ratna Kutha, Nyoman. 2004. Teori, Metode, dan Teknik Penelitian Sastra. Yogyakarta: Pustaka Pelajar.

Semi, M. Atar. 1989. Kritik Sastra. Bandung : Angkasa.

Siswanto Wahyudi. 2008. Pengantar Teori Sastra. Jakarta : PT Grasindo.

Sumardjo, Jakob dan K.M. Saini. 1988. Apresiasi Kesusasteraan. Jakarta: PT. Gramedia.

Teeuw, A. 1984. Sastra dan Ilmu Sastra. Jakarta : Pustaka Jaya.

Tim Penyusun Kamus Pusat Bahasa. 2005. Kamus Besar Bahasa Indonesia (KBBI). Jakarta : Balai Pustaka.

Wellek, Austin Warren.1989. Teori Kesusastraan. Jakarta: PT Gramedia 